DOI: https://doi.org/10.15407/kvt192.02.072

UDC 004.4:616.89-008.45/.47-02:616.831-005

L.M. RYSOVANA ${ }^{1}$, Assistant,

Department of Medical and Biological Physics and Medical Informatics

e-mail: rluba_24@ukr.net

O.V. VYSOTSKA ${ }^{2}$, D.Sc. (Engineering), Professor,

Professor of the Department of Information Control Systems

e-mail: evisotska@ukr.net

${ }^{1}$ Kharkov National Medical University,

Nauky ave., 4, 61022, Kharkiv, Ukraine

${ }^{2}$ Kharkov National University of Radio Electronics,

Nauky ave., 14, 61166, Kharkiv, Ukraine

\title{
INFORMATION SYSTEM OF DETECTION OF EMOTIONAL AND COGNITIVE DISORDERS IN PATIENTS WITH DISCIRCULATORY ENCEPHALOPATHY
}

Introduction. In modern conditions, there are topical issues of studying the mechanisms of formation and specificity of clinical manifestations of discirculatory encephalopathy in the able-bodied population. A large number of interrelated indicators that characterize emotional and cognitive disorders, the analysis of which requires the use of mathematical methods and software, determined the need to develop an information system for the detection of emotional and cognitive disorders in patients with discirculatory encephalopathy.

The purpose of the article is to develop a medical information system for the detection of emotional and cognitive disorders in patients with discirculatory encephalopathy, which increases the accuracy of diagnosis.

Materials and methods. The article uses mathematical statistics methods for processing diagnostic information; methods of mathematical modeling for constructing mathematical models for detecting the likelihood of emotional disorders and identifying and determining the severity of cognitive disorders in patients with discirculatory encephalopathy; methodical bases of construction of information technologies in medicine at construction of information system of revealing emotional and cognitive disorders in patients with discirculatory encephalopathy.

Results. During the writing of the article, a method was developed for detecting emotional and cognitive disorders in patients with discirculatory encephalopathy, including the definition of the likelihood of emotional disorders, the exposure vector for psychocorrection, the detection of cognitive disorders and determining their severity, and predicting the further development of cognitive disorders. A structural diagram of the medical information system "CognitiveDE" has been developed, which determines the composition and purpose of its main modules, and has allowed to develop a methodological basis for describing the interac-

(c) L.M. RYSOVANA, O.V. VYSOTSKA, 2018 
tion of the elements of the biological and technical subsystems. The software of the medical information system "CognitiveDE" was verified, which showed the compliance of the results of the individual stages of the system development with the requirements and restrictions formulated for them.

Conclusions. Using the developed method for detecting emotional and cognitive disorders in patients with discirculatory encephalopathy, based on developed mathematical models for determining the likelihood of emotional disorders and determining the severity of cognitive disorders, allows correctly diagnosing emotional and cognitive disorders.

The presented medical information system can be used by doctors of the neurological and psychiatric departments and medical psychologists to improve the accuracy and reduce the time of diagnosis of emotional and cognitive disorders.

Keywords: medical information system, assessment method, cognitive and emotional disorders, discirculatory encephalopathy.

\section{INTRODUCTION}

The cerebrovascular diseases (CVD) represent today a significant social and economic problem throughout the world $[1,2]$.

In recent years there has been a persistent tendency of increasing the chronic form of CVD (discirculatory encephalopathy (DEP)). In modern conditions, there are topical issues of studying the mechanisms of formation and specificity of clinical manifestations of DEP in the able-bodied population [1].

The majority of patients with organic and symptomatic mental disorders that occur against the background of cerebrovascular pathology, marked cognitive and emotional disorders (CD and ED) of varying severity. Disorders of mental activity and negative psychological factors complicate the course of the disease, restoration and rehabilitation processes, become one of the main causes of temporary disability and disability of patients. Numerous studies have shown that more than $50 \%$ of cases of mild cognitive impairment pass into one or another variant of dementia [2].

A large number of interrelated indicators that characterize CD and ED, the analysis of which requires the use of mathematical methods and software, determined the need to develop an information system for detecting cognitive and emotional disorders in patients with DEP.

\section{PROBLEM STATEMENT}

Currently, a number of information systems are used in psychoneurological practice. To identify and determine the degree of severity of the CD, information system "TESTER" is intended [3], but it allows to forecast the further development of this disorder and does not take into account the possibility of patients having cerebrovascular diseases.

One of the computer systems for psycho-diagnostics is the SMOL-Expert system [4], which is based on the SMOL-test, designed for psychological counseling. The resources of this computer system allow for testing, processing results, maintaining a database and interpreting survey results. However, generation of a large number of variants of output of results, which the system issues, significantly complicates the diagnostic process and lowers its accuracy. 
To determine the level of psychomotor development and control its dynamics in children, the expert system "Longitude" is used. It should be noted that the extended version of this system "Longitude +", which includes applied techniques, through which psychological work is carried out with adolescents and adults [5]. The disadvantage of this system is that it is designed to assess the condition of a conditionally healthy person, i.e. it does not allow to objectively assessing the mental state in patients with cerebrovascular diseases.

Automation of the process of conducting an outpatient card for patients in the psychiatric and narcological department can be carried out using the automated "Map of the patient who has applied for psychiatric care", which greatly facilitates the work of psychiatrists, especially young specialists [6], but it does not automate data analysis on the patient's condition, namely, to identify and determine the severity of ED and CD.

The "Aimedika" support system for making medical decisions (SSMMD) forms a list of the most likely diseases, based on the data of more than 22 million scientific articles on medical topics and the results of clinical practice in various medical specializations [7]. However, the disadvantage of this SSMMD, due to a rather impressive list of possible diseases, is the low accuracy of detecting and predicting cognitive and emotional disorders in patients with DEP.

The use of neural network systems is a justified and promising direction in predicting the development of the disease in patients with DEP, against the background of a large number of clinical parameters that are among themselves in a nonlinear connection. An example of this is the NeuroPro 0.25 hardwaresoftware complex [8], which allows to forecast the development of a DEP based on the use of an artificial neural network. However, the diagnosis and prediction of this disease with the help of this complex is difficult.

Thus, the analysis of the existing MIS has shown that at present a number of known medical and psychological systems that allow to diagnose disorders of the emotional and cognitive spheres in a CVD chronic form, but they do not cover the entire specifics of these disorders, and accordingly they do not have high diagnostic accuracy.

The purpose of this work is to develop a medical information system for the detection of emotional and cognitive impairment in patients with discirculatory encephalopathy.

To achieve this aim, it is necessary to solve the following tasks:

- to develop a method for detecting emotional and cognitive impairment in patients with discirculatory encephalopathy;

- to develop a structural diagram of the medical information system that allows to identify emotional and cognitive impairments in patients with discirculatory encephalopathy, reflecting the work of all its modules.

\section{MATERIALS AND METHODS OF RESEARCH}

When developing the method for detecting ED and CD, the optimal sample size was determined. So, with a reliability level of $\gamma=0.95$ and a maximum error of $5 \%$, the required sample size was $236-350$ people. For this study, a group of 350 patients aged 33 to 65 years was formed. 
All patients underwent examination, which used clinico-psychopathological, clinical-anamnestic, psychodiagnostic, psychological, laboratory-diagnostic, instrumental methods [1]. Thus, 135 indicators were obtained reflecting the somatic and psychoemotional state of health of patients with DEP.

The article uses mathematical statistics methods for processing diagnostic information; methods of mathematical modeling for constructing mathematical models for detecting the probability of ED and detecting and determining the degree of severity of CD in patients with DEP; methodical bases of construction of information technologies in medicine when building an information system for detecting cognitive and emotional disorders in patients with discirculatory encephalopathy.

\section{DEVELOPMENT OF A METHOD FOR DETECTING EMOTIONAL AND COGNITIVE IMPAIRMENT IN PATIENTS WITH DEP}

To analyze the development of DEP, it is necessary to perform a number of interrelated steps: determining the likelihood of occurrence of ED, identifying the impact vector for conducting psychic correction, identifying $\mathrm{CD}$ and determining their severity, predicting the further development of CD in patients with DEP.

Let there be some set of patients with DEP:

$$
Q=\left\{q_{j}\right\}
$$

where $j=\overline{1, m}$ - patient serial number.

Let there also be a finite set $X$ of n possible indicators of the state of patients with DEP:

$$
X=\left\{x_{i}\right\},
$$

where $i=\overline{1, n}$ - state index number.

$X$ is the union of two subsets:

$$
X=X^{P S Y} \cup X^{D I A G},
$$

where $X^{P S Y}$ — subset of psychological indicators, $X^{D I A G}$ — subset of somatic indices.

As the values of these parameters in the $j$-th patient are different, the subset of the values of the psychological state $q_{j}$ of the patient is defined as $X_{j}^{P S Y} \subset X_{j},\left|\mathrm{X}_{\mathrm{j}}^{\mathrm{PSY}}\right|=82$, a subset of the values of the indicators of the somatic state as $X_{j}^{D I A G} \subset X_{j},\left|\mathrm{X}_{\mathrm{j}}^{\mathrm{DIAG}}\right|=53$.

In determining the emotional status, depending on the indices $X_{j}$, each patient $q_{j}$ can be attributed to one of two groups of a finite set $\mathrm{L}=\left\{1_{\mathrm{v}}\right\}$, where $v=\overline{1,2}$ - group number. So, $l_{1}$ - absence of ED, $l_{2}$ - presence of ED.

To assign $q_{j}$ to one of the classes of a finite set $L$, it is necessary to construct a mathematical model defining the projection:

$$
X_{j} \stackrel{P}{\longrightarrow} L:\left\{q_{j} \in L_{v} \mid \mathrm{P}\right\}
$$

where $P$ - probability of the $j$ th patient falling into one of the two groups. 
In determining the cognitive status, depending on the indices $X_{j}$, each patient $q_{j}$ might be attributed to one of the three groups of a finite set $\mathrm{B}=\left\{\mathrm{b}_{\mathrm{g}}\right\}$, where $g=\overline{1,3}$ - group number. So, $b_{1}$ - absence of $\mathrm{KH}, b_{2}$ - lungs $\mathrm{KH}, b_{3}$ - moderate $\mathrm{KH}$.

To assign $q_{j}$ to one of the classes of the finite set $B$, it is necessary to construct a mathematical model defining the projection:

$$
X_{j} \stackrel{F}{\longrightarrow} B:\left\{q_{j} \in B_{g} \mid \mathrm{F}\right\}
$$

where $F$ - the values of the functions of the $j$-th patient in the $g$-th group.

Observations were made on $m$ objects, each of which is characterized by the $n$-dimensional vector of features.

For each $q_{j}$, it is known that it belongs to one of the two groups $l_{l}$ or $l_{2}$, in addition, the same patient belongs to one of the three groups $b_{1}, b_{2}$ or $b_{3}$.

Thus, the task is as follows: to develop a method based on the model for identifying the probability of ED, allowing for the implementation $X_{\mathrm{j}}=\left(x_{1}, x_{2}, \ldots, x_{n}\right)$ newly admitted to the examination of the patient refer it to one of two groups $l_{1}$ or $l_{2}$, and the model, determining the degree of severity of $\mathrm{CD}$, which allows the patient to be assigned to one of the three groups $b_{1}, b_{2}$ or $b_{3}$ for the realization of the same $X_{j}$.

The method of detecting emotional and cognitive impairment in patients with DEP consists of a number of stages.

At the first stage the data array was formed $X=\left\{X_{i j}\right\}$, where $x_{i j}$ - the value of the $i$ th indicator of the state of the $j$ th patient.

At the second stage, all quantitative, nominal and ordinal indicators of the patient's condition were subject to normalization and coding.

To bring the selected indicators to a single scale, linear scaling formulas were used:

for indicators like "the less, the better":

$$
\hat{x}_{\mathrm{ij}}=\frac{x_{i j}-x_{\text {min }}^{\prime}}{x_{\text {max }}^{\prime}-x_{\text {min }}^{\prime}} ;
$$

for indicators like "the more, the better":

$$
\hat{x}_{\mathrm{ij}}=\frac{x_{\text {max }}^{\prime}-x_{i j}}{x_{\text {max }}^{\prime}-x_{\text {min }}^{\prime}},
$$

where $\hat{x}_{\mathrm{ij}}$ is the normalized $i$ th index of the $j$ th patient, $x_{i j}$ is the eigenvalue of the $i$ th parameter of the $j$ th patient, $x_{\text {min }}^{\prime}$ and $x_{\text {max }}^{\prime}$ are respectively the minimum and maximum possible value of the indicator.

Thus, in this case, $\hat{x}_{i j} \in[0,1]$ the best state indices for the $j$ th patient correspond to zero, and the worst for the unit.

The third stage of the method was the determination of the probability of ED on the basis of the logistic regression model [9]. 
The probability of occurrence of ED was determined by the formula:

$$
P=\frac{e^{d}}{1+e^{d}},
$$

where $d=-19,26+0,82 X_{1 j}-0,50 X_{2 j}+0,94 X_{3 j}-0,46 X_{4 j}+0,96 X_{5 j}-1,53 X_{6 j}+$ $+1,60 X_{7 j}, X_{1 j}$ - trustfulness-suspicion, $X_{2 j}$ - straightforwardness-diplomacy, $X_{3 j}$ - level of fibrinogen, $X_{4 j}$ - anxiety, $X_{5 j}$ - depression, $X_{6 j}-$ psychosocial stress indicator and $X_{7 j}$ - blood glucose level [9].

At the fourth stage of the method, signs were identified that required priority correction.

Included in the mathematical model of determining the probability of occurrence of ED indicators were ranked and cut off those whose level was from 0 to 0.5 .

$$
\tilde{x}_{i j}=\left\{\hat{x}_{\mathrm{ij}} \mid \hat{x}_{\mathrm{ij}}>0,5\right\} \text {, }
$$

where $\tilde{x}_{i j}$ - ranked indicator.

To determine the optimal set of features that require an initial correction, the product of the sensitivity of each feature $\beta_{i}$ with its value $\tilde{x}_{i j}$ was calculated:

$$
\begin{gathered}
x_{\mathrm{ij}}^{*}=\left(x_{1 \mathrm{j}}^{*}, x_{2 \mathrm{j}}^{*}, \ldots, x_{\mathrm{nj}}^{*}\right), n=M\left(\tilde{x}_{i j}\right), \\
x_{\mathrm{ij}}^{*}=\beta_{i} \cdot x_{i j}, \\
x_{\mathrm{ij}}^{*} \leq x_{\mathrm{ij}+1}^{*},
\end{gathered}
$$

where $M$ - cardinality of the set of indices of the calculated exponents.

The calculated optimal vector of influence on the emotional state of the patient made it possible to conduct a psycho-correction quickly and qualitatively.

The fifth stage of the method was the identification and determination of the degree of severity of CD based on the construction of discriminant functions [1].

$$
\begin{gathered}
\quad \mathrm{F}_{1}(X)=4,61+1,65 \cdot A_{1 j}+1,32 \cdot A_{2 j}+1,67 \cdot A_{3 j}-0,24 \cdot A_{4 j}+1,42 \cdot A_{5 j}- \\
-1,31 \cdot A_{6 j}-2,04 \cdot A_{7 j}+1,07 \cdot A_{8 j}-0,92 \cdot A_{9 j}-2,32 \cdot A_{10 j}+1,44 \cdot A_{11 j} \\
\mathrm{~F}_{2}(X)=-23,57+0,29 \cdot A_{1 j}+0,68 \cdot A_{2 j}-0,06 \cdot A_{3 j}+0,28 \cdot A_{4 j}+0,10 \cdot A_{5 j}+ \\
+0,57 \cdot A_{6 j}+1,77 \cdot A_{7 j}-0,53 \cdot A_{8 j}-0,14 \cdot A_{9 j}+1,25 \cdot A_{10 j}-0,75 \cdot A_{11 j}
\end{gathered}
$$

where $A_{1 j}$ - stage of DEP, $A_{2 j}$ is the depression index, $A_{3 j}$ - anxiety index, $A_{4 j}$ - physical functioning, $A_{5 j}$ - probability of ED, $A_{6 j}$ - psychological health, $A_{7 j}$ - systolic pressure, $A_{8 j}$ - diastolic pressure, $A_{9 j}$ - number of red blood cells, $A_{10 j}$ - speed erythrocyte sedimentation, $A_{11 j}$ - prothrombin index, $F_{1}$ and $F_{2}$ - values of canonical discriminant functions [1].

At the sixth stage, a forecast is given for the further development of CD, using the Wald sequential analysis method [10].

After achieving the result of algebraic summation of the $D K$ values of the threshold amount, which is \pm 12.78 points, a favorable or unfavorable current is predicted $\mathrm{CD}$ [11]. 
At the seventh stage, a diagnostic conclusion is formed. Based on the calculated values of the probability of ED and discriminant functions, it is determined whether a particular patient belongs to one of the groups $l_{v}$ and $b_{g}$.

\section{DEVELOPMENT OF THE STRUCTURAL SCHEME OF MIS, ALLOWING TO IDENTIFY ED AND CD IN PATIENTS WITH DEP}

The developed method is the basis for MIS, which allows to identify ED and CD in patients with DEP. This system is an independent software and hardware tool that allows in the dialog or batch mode to process information and get all the necessary input data in the form of screen or printed forms.

The structural diagram of the developed information system "CognitiveDE" for a psychiatrist (doctor-psychotherapist, medical psychologist) (Fig. 1) is a logically linked interaction of the biological and technical subsystems.

The collection of information about the patient's condition is carried out as a result of clinical, psycho-pathological, clinical-anamnestic, psychodiagnostic, laboratory-diagnostic and instrumental studies, using diagnostic and laboratory-analytical equipment. The received information enters the information input module, where the initial set is formed, which is transmitted to the information processing module.

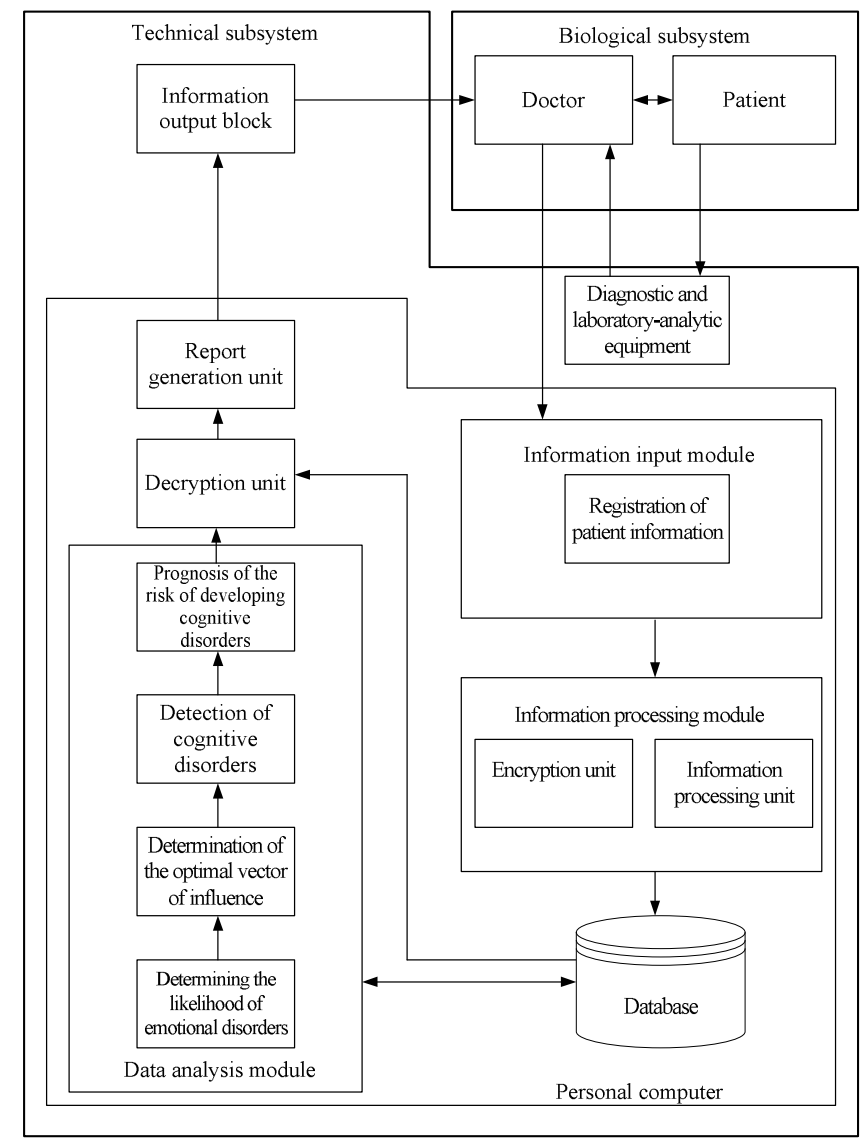

Fig. 1. Structural scheme of MIS of ED and CD detection 
The information processing module encodes information about the patient's condition and encrypts its passport data. As the most effective algorithm for protecting information, a symmetric algorithm of block-based AES encryption was chosen, which allowed to ensure confidentiality and prevent violation of data integrity and distortion.

Further, the processed data falls into the database. The developed database is characterized by a large amount of textual and numerical information about the patient's somatic and psychic emotional state.

At the stage of conceptual database design, entities were identified, between which there are one-to-many relationships. At the stage of physical database design, a data schema model was developed.

The database developed is open and cross-platform, which allows us to speak about the universal organization of its structure for solving problems of automating the diagnostic process of similar diseases.

Then the data goes to the data analysis module, where on the basis of the developed method, CD and ED are detected in patients with DEP, and the results obtained in this module are stored in the database for storage.

Then, in the decryption unit, the patient's patient data is restored by inverse transformation, using the same AES algorithm.

Then the information goes to the report generation unit, after which an opinion is generated, which is passed on to the specialist for the final acceptance of the medical decision.

To work with the system, a convenient and easy-to-use interface has been developed that makes it possible to register patients in an accessible form, to enter the results of surveys, to conduct psychological testing, etc., which is important in the work of medical personnel (Fig. 2).

The developed MIS "CognitiveDE" was implemented using an object-oriented Java programming language using the MySQL database management system.
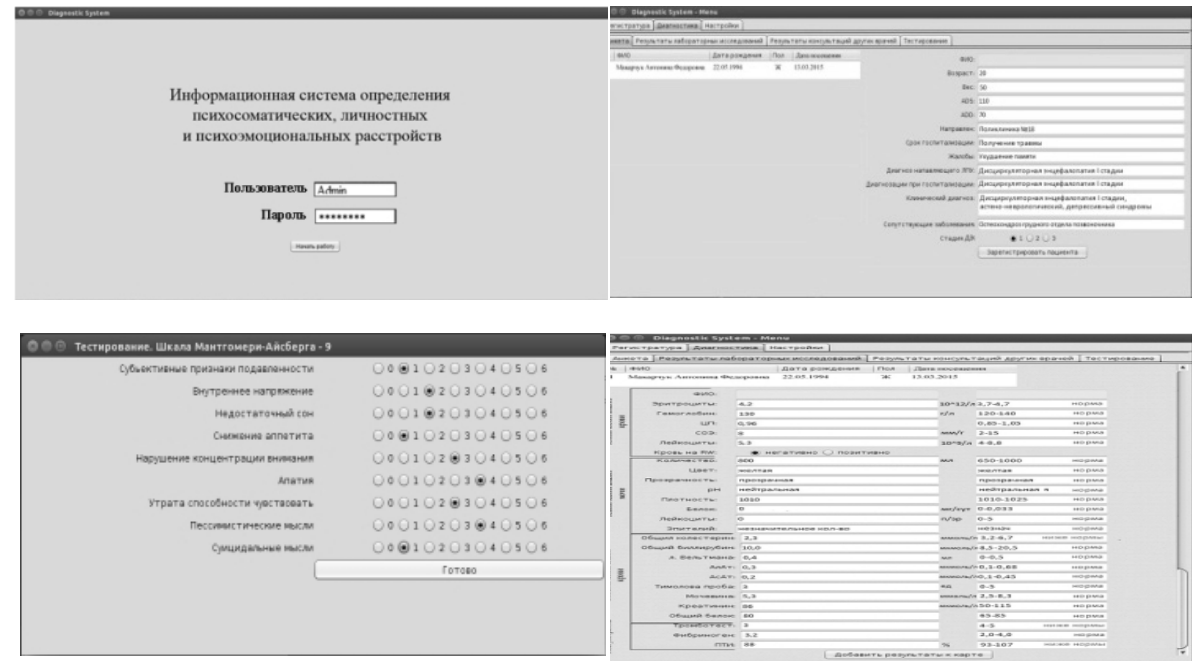

Fig. 2. Dialog windows of the "CognitiveDE" system 
Table 1. The results of the detection of emotional and cognitive impairment in patients with discirculatory encephalopathy

\begin{tabular}{|c|c|c|c|c|c|c|}
\hline \multirow{2}{*}{$n$} & \multicolumn{2}{|c|}{$T$} & \multicolumn{2}{|c|}{$V_{1}$} & \multicolumn{2}{c|}{$V_{2}$} \\
\cline { 2 - 7 } & $n_{1}$ & $\%$ & $n_{1}$ & $\%$ & $n_{1}$ & $\%$ \\
\hline 175 & 3 & $5,08 \pm 0,29$ & 3 & $5,17 \pm 0,30$ & 2 & $3,45 \pm 0,24$ \\
\hline
\end{tabular}

\section{QUALITY CONTROL OF SOFTWARE DEVELOPED BY MIS}

The usefulness of MIS "CognitiveDE" was tested in practice in the determination of emotional and cognitive impairment in 175 patients $(n)$ with DEP who were hospitalized in the Kharkov Regional Clinical Psychiatric Hospital No. 3 (59 people made a test sample $(T)$, and 116 - two validation samples $\left(V_{1}\right.$ and $\left.V_{2}\right)$ ), each patient underwent psychodiagnostic and laboratory-instrumental studies, in each of the samples a number of patients were identified who had erroneously detected emotional and/or cognitive impairments spheres $\left(n_{1}\right)$ and percentage of these errors $(\%)$.

The results of detection of ED and CD, obtained with the help of the developed system "CognitiveDE", showed that 167 patients out of 175 had the correct violations of emotional and cognitive spheres (Table 1). The accuracy of these violations was $95.43 \pm 0.16 \%$.

The quality of the software MIS "CognitiveDE" was tested using the demoversion of the program JHAWK version 6.0.

For the system level, the average cyclomatic complexity for all AVCC classes was 1.13, which indicates a good result, because AVCC $<5$ indicates a simple class [11]. The metric of the aggregate number of Halstead errors (HBUG) was tested, which showed the possibility of detecting a 3.52 error in the program code. This result indicates a quality software. Another important system metric is the program accompanying index (MI), the value of which is more than 100, which shows a high level of program maintenance [11].

Thus, the MIS has been developed to detect cognitive and emotional disorders in patients with DEP, which allows to improve the quality of diagnosis of CD and ED, and to reduce the time spent for this. The structural diagram of MIS "CognitiveDE" shows logically connected by interaction of biological and technical subsystems. The conducted testing of the system software showed its high quality.

\section{CONCLUSIONS}

We developed a method of detecting violations of the emotional and cognitive patients with circulatory encephalopathy, based on a mathematical model for determining the likelihood of emotional disorders, including such factors as: the credulitysuspicion, straightness-diplomacy, fibrinogen level, anxiety and depression, psychosocial stress index and the level of glucose in blood and correctly classifying $l_{v}$ group with a probability of 0.949 , and a mathematical model to identify and determine the degree of severity cognitive disorders consisting figures step circulatory encephalopathy, depression and anxiety, physical functioning, emotional disturbances probability, psychological health, systolic and diastolic blood pressure, red blood cell count, erythrocyte sedimentation rate, prothrombin index which correctly classifies $b_{g}$ group with a probability of 0.973 . 
A structural diagram of the medical information system "CognitiveDE" has been developed, which determines the composition and purpose of its main modules, and has allowed to develop a methodological basis for describing the interaction of the elements of the biological and technical subsystems. Presented information system can be used by physicians of neurological and psychiatric offices and clinical psychologist to improve accuracy and reduce diagnosis time emotional and cognitive disorders.

The verification of software medical information "CognitiveDE" system which has shown compliance with the requirements of the results of the individual steps of the system development and limitations set forth for them was held.

\section{REFERENCES}

1. Vysotskaya E.V., Kozhina A.M., Risovanaya L.M., Chaika H.E. Application of discriminant analysis for the classification of cognitive disorders in patients with discirculatory encephalopathy. Information processing system, 2013, Vol. 9, pp. 189-193. (In Russian).

2. Kozhina A.M., Grigorova I.A., Korosty V.I. and others. Organic mental disorders due to somatic diseases: cognitive and emotional disorders. Kharkov: Ukraine Rarities, 2012, 120 p. (In Ukrainian).

3. Aleksandrovsky Y.A., Shchukin B.P. Psychological disorders during and after natural disasters and disasters. Journal of Neuropathology and Psychiatry, 1991, Vol. 5, pp. 39-43. (In Russian).

4. Bleicher V.M., Krook I.V., Bokov S.N. Clinical Pathopsychology. Moskow, 2002, 511 pp. (In Russian).

5. Miroshnikov S.A. Expert system Longitude. The experimental and diagnostic complex (EDC). SPb: Lema, 2010, 196 pp. (In Russian)

6. Altamirov S.A. Application of information technology in the activities of a psychiatrist. Young Scientis, 2016, Vol. 29, pp. 200-203. (In Russian).

7. Aimedica. General information. http://aimedica.ru/info.jsp. (In Russian).

8. Kan L.V., Kuznetsova Y.M., Chudova N.V. Expert systems in the field of psychodiagnostics. Artificial Intelligence and Decision Making, 2010, Vol. 2, pp. 26-35. (In Russian).

9. Rysovana L., Vysotska O., Porvan A., Alekseenko R. Family crisis investigation on the basis of regression analysis. The problems of empirical research in psychology and humanities: Roland Barthes VIII International Scientific Conference. Europejskie Studia Humanistyczne: państwo i spoleczeństwo. Krakow, 2016, Vol. 2, p. 83-91.

10. Nechaeva G.I., Achmedov V.A., Bereznikov A.V. and others. Methodical approaches to the expert evaluation of the quality of therapeutic care for chronic cholecystitis. Therapeutic archive, 2010, Vol. 1, pp. 12-15. (In Russian).

11. Watson A., McCabe T. Structured testing: a testing methodology using the cyclomatic complexity metric. URL: http://www.mccabe.com/pdf/mccabe-nist235r.pdf. (Last accessed: 10.11.2017) 1996.

\section{ЛИТЕРАТУРА}

Received 26.02.2018

1. Высоцкая Е.В., Кожина А.М., Рисованая Л.М., Чайка Е.Э. Применение дискриминантного анализа для классификации когнитивных расстройств у больных дисциркуляторной энцефалопатией. Системи обробки інформаиіï, 2013, №9, с. 189-193.

2. Кожина А.М., Григорова I.А., Коростій В.І. и др. Органічні психічні розлади внаслідок соматичних захворювань: когнітивні та емоційні порушення. Х.: Раритети України, 2012, 120с.

3. Александровский Ю.А., Щукин Б.П. Психологические расстройства во время и после стихийных бедствий и катастроф. Журнал невропатологии и психиатрии, 1991, № 5, с. 39-43. 
4. Блейхер В.М., Крук И.В., Боков С.Н. Клиническая патопсихология. М.:, 2002, 511 с.

5. Мирошников С.А. Экспертная система Лонгитюд. Экспериментальнодиагностический комплекс (ЭДК). СПб.: Лема, 2010, 196 с.

6. Алтамиров С.А. Использование информационных технологий в деятельности врача-психиатра. Молодой ученьй, 2016, № 29, с. 200-203.

7. Аймедика. Общая информация. http://aimedica.ru/info.jsp .

8. Кан Л.В., Кузнецова Ю.М., Чудова Н.В. Экспертные системы в области психодиагностики. Искусственный интеллект и принятие решений, 2010, № 2, с. 26-35.

9. Rysovana L., Vysotska O., Porvan A., Alekseenko R. Family crisis investigation on the basis of regression analysis. The problems of empirical research in psychology and humanities: Roland Barthes VIII International Scientific Conference. Europejskie Studia Humanistyczne: państwo i spoleczeństwo. Krakow, 2016, № 2, p. 83-91.

10. Нечаева Г.И., Ахмедов В.А., Березников А.В. и др. Методические подходы к экспертной оценке качества терапевтической помощи при хронических холециститах. Терапевтический архив, 2010, № 1, с. 12-15.

11. Watson A., McCabe T. Structured testing: a testing methodology using the cyclomatic complexity metric. URL: http://www.mccabe.com/pdf/mccabe-nist235r.pdf. (Last accessed: 10.11.2017) 1996.

Получено 26.02.2018

Л.М. Рисованая ${ }^{1}$, ассистент,

каф. медицинской и биологической физики

и медицинской информатики,

e-mail: rluba_24@ukr.net

Е.В. Высоикая 2 , д-р техн. наук, проф.,

проф. каф. информационных управляющих систем

e-mail: evisotska@ukr.net

${ }^{1}$ Харьковский национальный медицинский университет,

г. Харьков, пр. Науки, 4, 61022, Украина

${ }^{2}$ Харьковский национальный университет радиоэлектроники,

г. Харьков, пр. Науки, 14, 61166, Украина

\section{ИНФОРМАЦИОННАЯ СИСТЕМА ВЫЯВЛЕНИЯ ЭМОЦИОНАЛЬНЫХ И КОГНИТИВНЫХ НАРУШЕНИЙ У ПАЦИЕНТОВ С ДИСЦИРКУЛЯТОРНОЙ ЭНЦЕФАЛОПАТИЕЙ}

Введение. В современных условиях актуальными являются вопросы выявления эмоциональных и когнитивных нарушений на фоне цереброваскулярных заболеваний хронической формы. Большое количество взаимосвязанных показателей, характеризующих эмоциональные и когнитивные нарушения, анализ которых требует применения математических методов и программных средств, определило необходимость разработки информационной системы выявления эмоциональных и когнитивных нарушений у пациентов с дисциркуляторной энцефалопатией.

Цель - разработать медицинскую информационную систему выявления когнитивных и эмоциональных нарушений у пациентов с дисциркуляторной энцефалопатией, позволяющей повысить точность диагностики.

Maтериалы и методы. В статье использованы методы математической статистики, математического моделирования и построения информационных технологий в медицине.

Pезультаты. Разработан метод выявления нарушений эмоциональной и когнитивной сферы у пациентов с дисциркуляторной энцефалопатией, включающий определение вероятности возникновения эмоциональных нарушений, выявление вектора воздействия для проведения психокоррекции, выявление когнитивных нарушений и определение их степени тяжести, прогнозирование дальнейшего развития когнитивных нарушений. Разработана структурная схема информационной системы, определены состав и назначения ее основных модулей, что позволило разработать методическую 
базу для описания взаимодействия элементов биологической и технической подсистем. Проведена оценка качества разработанного программного обеспечения медицинской информационной системы «CognitiveDE».

Bblвodb. Использование разработанной медицинской информационной системы «CognitiveDE» выявления когнитивных и эмоциональных нарушений у пациентов с дисциркуляторной энцефалопатией, в основу которой положен предложенный метод оценки дисциркуляторной энцефалопатии, позволяет повысить качество диагностики эмоциональных и когнитивных нарушений и сократить затрачиваемое для этого время.

Ключевые слова: медицинская информационная система, метод оценки, когнитивные и эмочиональные нарушения, дисииркуляторная эниефалопатия.

Л.М. Рисована, асистент,

каф. медичної та біологічної фізики і медичної інформатики

e-mail: rluba_24@ukr.net

O.B. Висоиька, д-р техн. наук, проф.,

проф. каф. інформаційних управляючих систем

e-mail: evisotska@ukr.net

${ }^{1}$ Харківський національний медичний університет,

пр. Науки, 4, м. Харків, 61022, Україна

${ }^{2}$ Харківський національний університет радіоелектроніки, пр. Науки, 14, м. Харків, 61166, Україна

\section{ІНФОРМАЦІЙНА СИСТЕМА ВИЯВЛЕННЯ ЕМОЦЙНИХ I КОГНІТИВНИХ ПОРУШЕНЬ У ХВОРИХ НА ДИСЦИРКУЛЯТОРНУ ЕНЦЕФАЛОПАТІЮ}

Bcmyn. В сучасних умовах актуальними $€$ питання виявлення емоційних і когнітивних порушень на тлі цереброваскулярних захворювань хронічної форми. Велика кількість взаємопов'язаних показників, які характеризують емоційні і когнітивні порушення, аналіз яких вимагає застосування математичних методів і програмних засобів, визначило необхідність розроблення інформаційної системи виявлення емоційних і когнітивних порушень у пацієнтів з дисциркуляторною енцефалопатією.

Мета. Розроблення медичної інформаційної системи виявлення когнітивних і емоційних порушень у пацієнтів 3 дисциркуляторною енцефалопатією, що дозволяє підвищити точність діагностики.

Результати. Розроблено метод виявлення порушень емоційної та когнітивної сфери у пацієнтів 3 дисциркуляторною енцефалопатією, який включає визначення ймовірності виникнення емоційних порушень, виявлення вектора впливу для проведення психокорекції, виявлення когнітивних порушень і визначення їх ступеня тяжкості, прогнозування подальшого розвитку когнітивних порушень. Розроблено структурну схему інформаційної системи, визначено склад і призначення її основних модулів, що дозволило розробити методичну базу для опису взаємодії елементів біологічної та технічної підсистем. Проведено оцінювання якості розробленого програмного забезпечення медичної інформаційної системи «CognitiveDE».

Висновки. Використання розробленої медичної інформаційної системи «CognitiveDE» виявлення когнітивних і емоційних порушень у пацієнтів з дисциркуляторною енцефалопатією, в основу якої покладено запропонований метод оцінювання дисциркуляторної енцефалопатії, дозволяє підвищити якість діагностики емоційних і когнітивних порушень і скоротити витрачений на це час.

Ключові слова: медична інформаційна система, метод оцінювання, когнітивні та емоційні порушення, дисциркуляторна енцефалопатія. 